\title{
Sports nutrition
}

\author{
Milena Tomanić ${ }^{1}$
}

${ }^{1}$ Katedra za higijenu sa medicinskom ekologijom, Medicinski fakultet, Univerzitet u Beogradu, Srbija

Kontakt: milena.tomanic@yahoo.com

\section{Sažetak}

S obzirom na veću energetsku potrošnju, fizički aktivne osobe imaju i povećane nutritivne zahteve. Pored drugih važnih faktora za bavljenje sportom, kao što su dobro zdravstveno stanje i fizička predispozicija, adekvatna ishrana predstavlja fundamentalnu komponentu. Ishrana sportista mora da bude dobro isplanirana i individualno prilagođena na osnovu telesnih karakteristika, tendencije ka dobijanju u težini ili mršavljenju, učestalosti, dužini i intenzitetu treninga. Studije su pokazale da dobro balansiran odnos makro- i mikronutrijenata, uz podršku suplemenata i adekvatnu hidrataciju, može da značajno unapredi sportske performanse i odigra ključnu ulogu u postizanju boljih rezultata. Optimalno dizajniran program ishrane, sa realnim i dostižnim ciljevima, koji se nadovezuju na dobro isplanirane treninge, predstavlja osnov za uspešno bavljenje sportom. Samo ispunjeni nutritivni zahtevi mogu da preveniraju deficite i unaprede sportska dostignuća do krajnjih granica.

Ključne reči: ishrana, dijeta, sport, sportisti, suplementi, hidratacija

\section{Uvod}

Prema Insitutu Mulier (Holandija) (1), preko 60 miliona ljudi u Evropi su članovi nekog sportskog kluba. Kada se tome doda broj rekreativaca u svim vidovima fizičke aktivnosti postaje jasno kolika je razmera sportske populacije. Uprkos potencijalno negativnim ishodima, kao što su relativno česte povrede i slično, preovlađuje jedinstveno mišljenje da pozitivni aspekti bavljenja sportom umnogome nadmašuju negativne (2). Brojne studije ukazuju da fizička aktivnost i sport imaju pozitivne efekte na razvoj ličnosti, kao i na emotivno i psihosocijalno sazrevanje kod mladih. U poređenju sa vršnjakinjama koje se nisu bavile sportom, sportistkinje u srednjoj školi ređe su stupale u seksualne odnose, ređe konzumirale alkohol, cigarete i drogu i u manjem broju slučajeva patile od depresije (3).

\section{Abstract}

Due to higher energy consumption, physically active people have higher nutritional requirements. In addition to other important factors for sports, such as good health and physical predisposition, adequate nutrition is a fundamental component. Sports nutrition must be well planned and individually adapted based on physical characteristics, tendencies towards gaining or losing weight, frequency, duration and intensity of training sessions. Studies have shown that a well-balanced ratio of macro and micronutrients, with the support of supplements and adequate hydration, can significantly improve athletic performance and plays a key role in achieving better results. An optimally designed nutritional program, with realistic and achievable goals, which complements a well-planned training program, is the basis for success in sports. Only when nutritional requirements are met, deficits can be prevented and performance in sport pushed to the limit.

Key words: nutrition, diet, sport, athlete, supplements, hydration

Pored drugih važnih faktora koji predstavljaju osnov za uspešno bavljenje sportom, kao što su fizička predispozicija, dobro zdravstveno stanje, posvećenost sportu i jaka motivacija, redovni treninzi, rad na brzini, snazi, tehnici i drugim veštinama koje odgovaraju na specifične zahteve svakog sporta (4), adekvatna ishrana predstavlja fundamentalnu komponentu. Ishrana sportista je prepoznata kao ključni faktor za postizanje dobrih rezultata $(5,6)$.

\section{Opšti nutritivni ciljevi u sportu}

Optimalan unos energije kod sportista predstavlja imperativ iz više razloga. Važno je, pre svega, podmiriti potrebe organizma za makro- i mikronutrijentima, neophodne za normalno funkcionisanje i očuvanje dobrog zdravlja. 
Unos energije utiče na izgradnju mišićne mase i nivoa masti koji su od izuzetnog značaja za postizanje visokog nivoa fizičke spremnosti, kao i na funkciju hormonskog i imunog sisitema. Održavanje energije i dobar balans tečnosti imaju važnu ulogu tokom sportskih aktivnosti i predstavljaju osnovu za specijalne nutricionističke programe (7).

Svaki sportista ima individualne energetske zahteve. Oni su uslovljeni telesnom masom i visinom, tendencijom ka dobijanju u težini ili mršavljenju i prilagođeni su učestalosti, dužini i intenzitetu treninga (8). Program treninga kod sportista razlikuje se prema vrsti samog takmičenja i fazama sportske sezone, pa ishrana treba da bude usklađena prema tome.

Rezultati ispitivanja otkrivaju da sportisti tokom intenzivnog treninga troše između 3000 i $5000 \mathrm{kcal}$. Deca i tinejdžeri treba da unesu adekvatnu količinu hranljivih materija neophodnih za normalan rast i razvoj, a preko toga još i energiju za vežbanje različitog intenziteta (9).

Iako je veliki broj onih koji su sposobni da održe balans energije tokom dužeg perioda, otkriveno je da su sportisti često suočeni sa problemima koji se odnose na unos energije kod ekstremno visokih ili ekstremno niskih zahteva. Korist od pravilnog načina ishrane najviše dolazi do izražaja u takmičarskom delu bavljenja sportom, gde adekvatna nutritivna strategija omogućava da takmičar pruži svoj maksimum. Iako je od naročite važnosti stručno planirana ishrana u fazama takmičenja, svakodnevni režim ishrane čini osnov u izgradnji telesne kompozicije i održavanju zdrave i snažne strukture koja omogućava sportistima da se takmiče.

\section{Uticaj sporta na kontrolu telesne težine}

Neki sportisti imaju telesnu konstituciju predodređenu za sport kojim se bave, pa lako postižu i održavaju idealnu telesnu formu. Drugi moraju da vrše korekcije u vidu smanjenja ili povećanja telesne mase ili promene odnosa mišićnog i masnog tkiva, a to postižu prilagođavanjem ishrane usmerenim treninzima.

Istraživanje kojim je procenjivan međusobni odnos telesnih dimenzija i veštine izvođenja fundamentalnih pokreta među decom i adolescentima pokazalo je da prekomerno povećanje telesne mase smanjuje veštinu izvođenja pokreta (10). Pošto je dostizanje idealne mase i željene telesne strukture od ključnog značaja za ostvarenje vrhunskih rezultata, mnogi sportisti su izloženi povećanom riziku od unosa nedovoljne količine hranljivih materija. U praksi je često prisutan restriktivan unos kalorija koji se sreće kod sportista, naročito žena (11).
Istraživanje sprovedeno na rekreativcima muškog i ženskog pola pokazalo je da $23 \%$ muškaraca i $63 \%$ žena unose neadekvatne količine hranljivih materija zato što žele da smanje telesnu težinu (12). Ovaj problem naročito dolazi do izražaja u sportovima koji naglašavaju telesnu figuru ili prave podele prema težinskim kategorijama (npr. ritmička gimnastika, umetničko klizanje i ples, džudo, boks i drugi), gde regulacija telesne težine, između ostalog, može da ima odlučujuću ulogu u uspehu $(13,14)$.

Pritisak kompetitivnih sportova stvara veliki rizik za razvoj patološke kontrole telesne težine kod oba pola (15). Gubitak telesne masti trebalo bi da bude dostignut isključivo kroz program baziran na umerenom i postepenom gubitku energije.

\section{Hranljive materije bogate energijom}

Energiju potrebnu za ćelijske funkcije tokom mirovanja i mišićnog napora telo dobija iz ugljenih hidrata, masti i proteina.

Energija za rad mišića može da bude stvorena anaerobno, procesom glikolize, gde se isključivo razlažu glukoza ili glikogen, ili aerobno, Krebsovim ciklusom, gde se metabolički proizvodi glikolize koriste zajedno sa masnim kiselinama putem procesa beta oksidacije. Kada je telo u mirovanju, većina energije (oko 60\%) dolazi od sagorevanja masti, dok je značajno manji (oko 35\%) udeo ugljenih hidrata. Preostalih $5 \%$ u proseku potiče iz proteina. Tokom mišićnog napora relativno učešće goriva u proizvodnji potrebne energije zavisi od intenziteta i trajanja vežbanja, kao i od ishrane i nivoa treninga sportiste (16).

\section{Ugljeni hidrati}

Ljudski organizam ima rezervu od oko $500 \mathrm{~g}$ ugljenih hidrata. Najveći deo ugljenih hidrata je uskladišten u formi glikogena u mišićima (oko $450 \mathrm{~g}$ ) i jetri (oko $50 \mathrm{~g}$ ), a svega $15 \mathrm{~g}$ u obliku glukoze u krvi. Ishrana bogata ugljenim hidratima može skoro da duplira rezerve u mišićima i jetri, dok će ishrana sa smanjenim unosom ugljenih hidrata imati suprotan efekat (16).

Potrebe sportista za ugljenim hidratima zasnivaju se na nekoliko faktora. Sportisti moraju da unesu dovoljno ugljenih hidrata da bi obezbedili dovoljno energije i zadovoljili većinu potreba za kalorijama, kako bi rezerve glikogena učinili optimalnim, omogućili oporavak mišića nakon fizičke aktivnosti, obezbedili brzo i lako dostupan izvor energije između obroka i održali optimalan nivo glukoze u krvi. Glukoza predstavlja glavni izvor energije za mišićnu aktivnost. Sa povećanjem intenziteta vežbanja javljaju se sve veće potrebe za glukozom kao energetskim gorivom. Održavanje količine ugljenih hidrata na visokom nivou je veoma zahtevno jer su, za razliku 
Tabela 1. Preporuke za unos ugljenih hidrata u skladu sa fizičkom aktivnošću

\begin{tabular}{lll}
\hline Aktivnost & Preporučeni unos UH & Primer \\
\hline $\begin{array}{l}\text { Neposredan oporavak nakon } \\
\text { vežbanja (0 do 4 sata) }\end{array}$ & $\begin{array}{l}1 \mathrm{~g} / \mathrm{kg} \mathrm{TM} / \mathrm{h} \\
\text { (konzumirano u čestim } \\
\text { intervalima) }\end{array}$ & $\begin{array}{l}\text { Sportista težak } 70 \mathrm{~kg} \text { treba da unosi } 70 \mathrm{~g} \text { UH (280 kcal) neposredno } \\
\text { nakon vežbanja, a zatim dodatnih } 70 \mathrm{~g} \text { svakog sata naredna } 4 \text { sata }\end{array}$ \\
$\begin{array}{l}\text { Dnevni unos: } \\
\text { trening umerenog trajanja }\end{array}$ & $5-6 \mathrm{~g} / \mathrm{kg} \mathrm{TM} / \mathrm{dan}$ \\
$\begin{array}{l}\text { i niskog intenziteta } \\
\begin{array}{l}\text { Dnevni unos: } \\
\text { trening izdržljivosti umerenog } \\
\text { do visokog intenziteta }\end{array}\end{array}$ & $\begin{array}{l}\text { Sportista težak } 70 \mathrm{~kg} \text { treba da unosi } 350 \mathrm{do} 490 \mathrm{~g} \mathrm{UH}(1400 \mathrm{do} 1960 \\
\text { kcal) tokom celog dana. U tu količinu je uračunata količina koja se } \\
\text { unosi radi oporavka neposredno nakon vežbanja }\end{array}$ \\
$\begin{array}{l}\text { Dnevni unos: } \\
\text { eksremni trenažni program koji } \\
\text { traje } 4 \text { i više sati dnevno }\end{array}$ & $10-12$ (ili više) $\mathrm{g} / \mathrm{kg} \mathrm{TM} / \mathrm{dan}$ TM/dan & $\begin{array}{l}\text { Sportista težak } 70 \mathrm{~kg} \text { treba da unosi } 490 \text { do } 840 \mathrm{~g} \text { UH (1960 do } 3360 \\
\text { kcal) tokom celog dana. U tu količinu je uračunata količina koja se } \\
\text { unosi radi oporavka neposredno nakon vežbanja }\end{array}$ \\
\hline
\end{tabular}

Adaptirano iz: L. Burke and E. Coyle, 2004, „Nutrition for athletes”, Journal of Sport Sciences 22(1): 39-55.

od mogućnosti ljudskog organizma da deponuje mast, kapaciteti za deponovanje ugljenih hidrata veoma ograničeni. Unos ugljenih hidrata naročito postaje značajan pri veoma intenzivnim treninzima jer se energetski metabolizam tada maksimalno oslanja na njih kao na izvor energije za mišiće. Brojne studije su pokazale da je nizak nivo ugljenih hidrata tokom vežbanja povezan sa relativno brzom pojavom zamora (17-19).

S obzirom na to da su rezerve ugljenih hidrata ograničene (350 kcal glikogena u jetri i 1400 kcal glikogena u mišićima), sportisti treba da razmotre strategiju kako da započnu vežbanje sa punim rezervama glikogena i kako da uspostave rutinu koja sprečava da se te rezerve drastično smanje. Dokazano je da veći intenzitet vežbanja zahteva ugljene hidrate kao dominantno gorivo za mišićnu kontrakciju, ali takođe i da vežbanje niskog intenziteta, za koje se energija dominantno crpi iz masti, i dalje zahteva izvestan nivo ugljenih hidrata za potpuno sagorevanje masti i za održavanje koncentracije glukoze u krvi. Dakle, svi oblici fizičke aktivnosti su u nekom stepenu zavisni od ugljenih hidrata (11).

Tradicionalan način za utvrđivanje potreba za ugljenim hidratima jeste razmatranje učešća ugljenih hidrata $u$ ukupnom unosu kalorija. Preporuke za opštu populaciju sugerišu unos ugljenih hidrata od 50 do $55 \%$ od ukupnog broja kalorija (20). Međutim količina koja se preporučuje sportistima iznosi 55 do $65 \%$ unosa kalorija iz ugljenih hidrata (11). Drugi, i svakako bolji način utvrđivanja potreba za ugljenim hidratima jeste da se u razmatranje uzme količina ugljenih hidrata (u gramima) koja treba da se konzumira po kilogramu telesne mase (Tabela 1).

Većina ugljenih hidrata trebalo bi da bude uneta iz žitarica, mahunarki, voća i povrća. Ako se prisetimo glikemijskog indeksa kao merila brzine kojom se ugljeni hidrati uneti ishranom apsorbuju i pojavljuju u cirkulaciji, za opštu populaciju je poželjno (uključujući i sportiste) da konzumira ugljene hidrate koji imaju nisku do srednju vrednost glikemijskog indeksa (banana, pomorandža, mekinje, testenina, integralni pšenični hleb, zobena kaša). Postoje periodi, međutim, (npr. za vreme i neposredno nakon vežbanja), kada bi za sportiste mogla da bude korisnija hrana sa visokoglikemijskim vrednostima (beli hleb, med, pečeni krompir, kukuruzne pahuljice). Uopšteno govoreći, namirnice bogate ugljenim hidratima sa višim sadržajem vlakana imaju niži glikemijski indeks, tako da predstavljaju dobar izbor za sportiste. Dijetetska vlakna, međutim, mogu da izazovu gasove i nadimanje, što znači da predstavljaju loš izbor namirnica za konzumiranje neposredno pre ili za vreme takmičenja. Namirnice od rastvorljivih (solubilnih) vlakana mogu da izazovu manje problema, ali se preporučuje da sportisti sami eksperimentišu da bi utvrdili koje namirnice najbolje podnose. Smatra se da se najlakše podnose skrobni ugljeni hidrati sa niskom koncentracijom vlakana, kao što su testenine (11).

\section{Masti}

Masti su idealna forma kroz koju ćelije mogu da skladište i troše energiju. Jedan gram masti sadrži oko $9 \mathrm{kcal}$, dvostruko više od jednog grama proteina ili ugljenih hidrata. Masti su uskladištene u obliku triglicerida u mišićnim ćelijama (oko $500 \mathrm{~g}$ ) i adipocitima (oko $14000 \mathrm{~g}$ ), dok je zanemarljiva količina $(0,4 \mathrm{~g})$ u plazmi u obliku slobodnih masnih kiselina $(11,16)$.

Iako su se u novijoj literaturi pojavljivale teze koje govore u prilog unosu velikih količina masti (unos 30\% ili više od ukupnih kalorija), treba naglasiti da su masti visokokoncentrovani izvor energije koji ne dovodi do poboljšanja sportskih rezultata kada se unosi u velikim količinama. Ne postoje relevantne naučne informacije koje ukazuju na to da je unos masti iznad $25 \%$ od ukupnih kalorija generalno koristan za sportiste (21). 
Sa stanovišta vežbanja, nije dokazano da povećanje unosa masti rezultira poboljšanjem sportskih rezultata, izuzev ako je povećan unos masti jedini način da sportista dobije dovoljno energije. Sportistima kojima je potrebno više od $4000 \mathrm{kcal}$ svakog dana da bi zadovoljili kombinovane potrebe rasta, vežbanja i regeneracije tkiva, može da bude potrebno umereno povećanje unosa masti u ishrani (poželjno biljnog ili ribljeg porekla). Pošto je mast koncentrovaniji oblik energije i od ugljenih hidrata i od proteina, više energije može se uneti u manjim količinama hrane ukoliko namirnice sadrže više masti. Ako bi sportista pokušao da potpuno obustavi unos masti, morao bi da konzumira toliko hrane da bi postalo nemoguće organizovati dovoljno obroka ili odvojiti dovoljno vremena za obroke da bi se konzumirala potrebna energija (11). Pošto sportisti deponuju više kalorija iz masti nego iz ugljenih hidrata, povećanje sposobnosti da se koriste masti uzrokuje proporcionalnu redukciju u oslanjanju na ugljene hidrate, čime se povećava izdržljivost. Jednostavno rečeno, ako se sagoreva više masti pri većem intenzitetu vežbanja, time će rezerve ugljenih hidrata trajati duže, čime se poboljšava izdržljivost.

Oksidacija masti, dakle, nikada ne može da dostigne taj nivo da eliminiše potrebu za ugljenim hidratima (glikogenom) za vreme intenzivnog vežbanja. Prema tome, veća sposobnost da se masti metabolišu za dobijanje energije ne treba da usmeri sportiste da povećaju proporcionalan unos masti. Pod pretpostavkom da je nivo unosa kalorija adekvatan, sportisti mogu da proizvedu i deponuju masti koje su im potrebne, a veći unos masti $u$ ishrani jasan je faktor rizika za pojavljivanje ateroskleroznih bolesti srca. Čak i kratkoročno povećanje unosa masti sa pratećim smanjenjem ugljnih hidrata u trajanju od samo 3 do 5 dana izaziva opadanje parametara izdržljivosti kada se uporede sa sposobnostima pri visokom unosu ugljenih hidrata (22). Što se tiče triglicerida, za većinu sportista maksimalan unos triglicerida srednje dugačkih lanaca ne treba da prelazi 30 grama $(270 \mathrm{kcal})$. Unos iznad pomenute količine u ogromnoj meri povećava rizik od pojave smetnji gastrointestinalnog trakta, uključujući i dijareju (23).

Zadnjih godina se sve veća pažnja posvećuje mogućim korisnim efektima omega 3 masnih kiselina u poboljšanju rezultata u sportu. Unos omega 3 masnih kiselina ostvaruje pozitivne efekte pospešujući aerobne metaboličke procese, što se pozitivno ispoljava i na rezultate sportista i na sposobnost pojedinca da efikasno koristi masti kao energetsko gorivo. To ne znači da je povećanje ukupnog unosa masti poželjno ili neophodno da bi se ostvarili pomenuti korisni efekti, ali sportisti mogu da razmotre promenu vrste masti koje unose $u$ ishranu time što će uključiti periodične ali redovne (jednom ili dva puta nedeljno) obroke lososa, albakor tune, atlantske haringe i ostalih riba hladnih dubokih mora u količini od 110 do 140 grama da bi povećali udeo omega 3 masnih kiselina koje su im na raspolaganju. U drugim studijama koje su ispitivale uticaj omega 3 masnih kiselina nisu nađena konzistentna poboljšanja snage i izdržljivosti, kao ni dokazi da omega 3 masne kiseline smanjuju bol u mišićima (24-26).

\section{Proteini}

Ugljeni hidrati i masne kiseline su prioritetno gorivo koje služi kao izvor energije tokom vežbanja. Sa produženim vežbanjem se smanjuju rezerve mišićnog glikogena, a počinju da se koriste proteini. Aminokiseline se konvertuju u jetri preko glukoneogeneze i dovode do oksidativnih procesa (16).

Mnogi sportisti imaju stav da su proteini najvažniji za postizanje dobrih rezultata u sportu. U sportovima snage sve više se koristi neka vrsta proteinske suplementacije. Suficitarnim unosom proteina smanjuje se mogućnost za adekvatan unos drugih esencijalnih hranljivih materija. Česte su i situacije u kojima su potrebe za proteinima veće nego što ih sportista unosi. Takmičari u sportovima aerobne izdržljivosti, koji izgledaju mršavo i manje mišićavo od npr. dizača tegova, zapravo imaju skoro jednako visoku potrebu za proteinima (po jedinici telesne mase) kao sportisti u sportovima snage $(27,28)$. Preporučeni dnevni nivo unosa proteina za opštu populaciju je $12-15 \%$ od ukupnog unosa kalorija, što bi iznosilo nekih 0,8 grama proteina po kilogramu telesne mase. Sportistima je potrebno više proteina zbog veće bezmasne telesne mase, veće potrebe za oporavkom tkiva i zato što se za vreme fizičkih aktivnosti sagoreva mala količina proteina. To kod sportista povećava potrebe za proteinima približno dvostruko u odnosu na potrebe onih koji nisu sportisti (1,2 do 1,7 grama po kilogramu) (Tabela 2) (11).

Tabela 2. Potrebe za proteinima fizički aktivnih ljudi

\begin{tabular}{|c|c|c|c|c|}
\hline \multirow[t]{2}{*}{ Tip aktivnosti } & \multirow{2}{*}{$\begin{array}{c}\text { Ukupna energija } \\
\text { (kcal/dan) }\end{array}$} & \multicolumn{3}{|c|}{ Proteini } \\
\hline & & $\mathrm{g} / \mathrm{kg} / \mathrm{dan}$ & g/dan & \% ukupnih kcal/dan \\
\hline Izdržljivost $(\mathrm{a}, \mathrm{b})$ & 3800 & $1,2-1,4$ & $84-98$ & $9-10$ \\
\hline Snaga $(a, c)$ & 3.200 & $1,6-1,7$ & $112-119$ & $14-15$ \\
\hline
\end{tabular}

a Pod pretpostavkom da potrošnja energije u miru iznosi $40 \mathrm{kcal}$ po kg telesne mase na dan

b Pod pretpostavkom da atletičar muškarac trči $16 \mathrm{~km}$ na dan tempom 3,7 minuta po km

c Pod pretpostavkom da je potrebno dodatnih $6 \mathrm{kcal}$ po kg telesne mase dnevno za trening sa velikim opterećenjem

Preuzeto iz Dr. M. J.Gibala, 2002. „Dietary protein, amino acid supplements, and recovery from exercise”, GSSI Sports Science Exchange, br. 87, 15(4) 
Tabela 3. Funkcije aminokiselina i proteina

\begin{tabular}{|c|c|}
\hline \multirow{4}{*}{$\begin{array}{l}\text { Funkcionalni proteini } \\
\text { (hemoglobin, enzimi, hormoni; } \\
\text { održavanje normalne osmolalnosti } \\
\text { krvi; antitela; izvor energije) }\end{array}$} & Enzimi \\
\hline & Antitela \\
\hline & $\begin{array}{l}\text { Transparentni } \\
\text { proteini }\end{array}$ \\
\hline & Hormoni \\
\hline \multirow{4}{*}{$\begin{array}{l}\text { Strukturni proteini } \\
\text { (konstituišu ćelijsku strukturu; } \\
\text { pomažu razvoj, obnavljanje i } \\
\text { održavanje tkiva) }\end{array}$} & $\begin{array}{l}\text { Mišići, tetive, } \\
\text { ligamenti }\end{array}$ \\
\hline & Koža \\
\hline & Zubna i koštana srž \\
\hline & Kosa i nokti \\
\hline
\end{tabular}

Prerađeno iz Benardot D. Napredna sportska ishrana; [translated by Halilovic R]. Beograd: Data Status, 2010. p 27.

Pravilo sportske ishrane jeste da ugljeni hidrati imaju efekat štednje proteina. To znači da će, ako sportista unese dovoljno ugljenih hidrata u energetske svrhe, proteini biti pošteđeni sagorevanja kako bi mogli da se iskoriste za mnogo važnije funkcije (Tabela 3 ).

Preporuke za povećanim unosom proteina kod sportista zasnivaju se na četiri faktora (29-31). Sportisti obično imaju veću bezmasnu telesnu masu, za čije je održavanje potrebno više proteina; oni putem urina gube malu količinu proteina (fenomen poznat kao proteinurija), sagorevaju malu količinu proteina za vreme fizičke aktivnosti (približno 5\% od ukupnog sagorevanja energije) i potrebna im je dodatna količina proteina da bi se oporavili od oštećenja mišića koja nastaju tokom trajanja treninga.

Visokoproteinske namirnice imaju nisku brzinu želudačnog pražnjenja, tako da se ne preporučuje njihova konzumacija neposredno pre ili za vreme vežbanja.

\section{Mikronutrijenti}

Vitamini i minerali (mikronutrijenti) su esencijalne hranljive materije koje učestvuju u brojnim fiziološkim funkcijama, ali i u sintezi i reparaciji mišićnog tkiva tokom oporavka od vežbanja i povreda. Kod prolongiranih sportskih aktivnosti povećava se rizik za nastanak oksidativnog stresa i javlja se povećana proizvodnja slobodnih radikala. Intenzivna fizička aktivnost stimuliše antioksidativnu odbranu, ali sportisti treba da raspolažu dovoljnom količinom antioksidanasa koji će se suprotstaviti slobodnim radikalima. Vitamini i minerali su antioksidansi koji smanjuju oksidativni stres nastao tokom vežbanja (32). Rutinsko vežbanje izaziva ",trošenje” i gubitak mikronutrijenata iz tela. Kao rezultat svega toga javlja se potreba za većim unosom mikronutrijenata koji će učestvovati u izgradnji, reparaciji i održavanju mišićnog tkiva kod sportista (33). Zbog toga je sportistima potrebno više različitih vrsta vitamina i minerala nego osobama koje se ne bave sportom. Većina sportista, međutim, ne shvata kolika količina određenih vitamina i minerala im je potrebna, niti razume principe optimalnog unosa za obezbeđivanje adekvatnih količina, tako da većina njih čini istu grešku i unosi preveliku količinu mikronutrijenata putem suplementacije.

Činjenica da mikronutrijenti imaju integrisane funkcije treba da ohrabri sportiste da obezbede najširi mogući spektar vitamina i minerala svojim ćelijama. Dodatni unos samo jednog vitamina ili samo jednog minerala može da naruši ravnotežu hranljivih materija i delikatan odnos između njih.

Institut za medicinu SAD je dao preporuke za unos vitamina i minerala na osnovu starosti, pola i trudnoće (Tabele 4 i 5 ).

Tzv. DRI (Dietary Reference Intakes) prilagođene su zdravim, umereno aktivnim osobama. S obzirom na to da diskrepanca između potreba sportista i umereno aktivnih ljudi nije prevelika, ove preporuke zadovoljavaju i potrebe sportista.

Sportisti koji se iz nekog razloga podvrgavaju restriktivnim dijetama ili imaju velike oscilacije u telesnoj težini, gde eliminišu određenu grupu namirnica iz ishrane ili konzumiraju hranu siromašnu mikronutrijentima, pod rizikom su da dospeju u mikronutritivni deficit. U ovakvim situacijama im se preporučuje da dnevnu nadoknadu vitamina i minerala realizuju putem suplemenata. Treba imati na umu da korišćenje suplemenata ne oslobađa sportistu obaveze da i dalje teži dobrom izboru hranljivih materija (34).

\section{Hidratacija}

Dobra hidriranost omogućava održavanje ravnoteže intraćelijske i ekstraćelijske tečnosti u organizmu i čini osnov za nesmetano obavljanje fizičke aktivnosti. Uprkos tome, većina sportista je nekad doživela određen stepen dehidracije. Imajući u vidu da se za vreme intenzivnog vežbanja oslobađa gromna količina znoja, sportisti su prinuđeni da nadoknađuju tečnost kako bi održali optimalno stanje vode u organizmu. Ako se tečnost ne nadoknadi dolazi do prevremenog zamora sa mogućnošću razvoja toplotnog udara. Od ključne važnosti za sportiste je da budu u stanju optimalne hidratacije pre započinjanja vežbanja ili takmičenja. Svi dokazi ukazuju na to da čak i minimalan stepen hipohidratacije (npr. deficit od svega $2 \%$ telesne mase) može da izazove merljive razlike u izdržljivosti i sportskim rezultatima. Što je stepen deficita veći negativan uticaj je izraženiji (35). 
Tabela 4. Preporučeni dnevni unos 13 esencijalnih vitamina

\begin{tabular}{lll}
\hline Vitamin & DRI - odrasli muškarci & DRI- odrasli žene (koje nisu tudne) \\
\hline Vitamin A & $900 \mu \mathrm{g}$ & $700 \mu \mathrm{g}$ \\
Vitamin D & $5 \mu \mathrm{g}$ & $5 \mu \mathrm{g}$ \\
Vitamin E & $15 \mu \mathrm{g}$ & $15 \mathrm{mg}$ \\
Vitamin K & $120 \mu \mathrm{g}$ & $90 \mu \mathrm{g}$ \\
Vitamin C & $90 \mathrm{mg}$ nepušači & $75 \mathrm{mg}$ nepušači \\
& $125 \mathrm{mg}$ pušači & $110 \mathrm{mg}$ pušači \\
Tiamin (B1) & $1,2 \mathrm{mg}$ & $1,1 \mathrm{mg}$ \\
Riboflavin (B2) & $1,3 \mathrm{mg}$ & $1,1 \mathrm{mg}$ \\
Niacin (B3) & $16 \mathrm{mg}$ & $14 \mathrm{mg}$ \\
Piridoksin (B6) & $1,3 \mathrm{mg}$ & $1,3 \mathrm{mg}$ \\
Kobalamin (B12) & $2,4 \mu \mathrm{g}$ & $2,4 \mu \mathrm{g}$ \\
Folati & $400 \mu \mathrm{g}$ & $400 \mu \mathrm{g}$ \\
Pantotenska kiselina & $5 \mathrm{mg}$ & $5 \mathrm{mg}$ \\
Biotin & $30 \mu \mathrm{g}$ & $30 \mu \mathrm{g}$ \\
\hline
\end{tabular}

* starosna dob od 19 do 50 godina

$\mathrm{DRI}=$ Dietary Reference Intake; $\mu \mathrm{g}=$ mikrogram; $\mathrm{mg}=$ miligram

Podaci preuzeti sa: Instituta za Medicinu, SAD, 2000.

Iako nije moguće izbeći određeni gubitak tečnosti, sportista treba da održava stepen deficita na prihvatljivom nivou i da razvije dobru strategiju nadoknade tečnosti pre, tokom i posle sportskog nastupa. Saznanja o postizanju optimalne hidratacije tokom vežbanja napredovala su u poslednjih 30 godina. Početni fokus koji se odnosio samo na potrebe za tečnošću evoluirao je do realizacije strategi- je koja omogućava da se potrebe za tečnošču i energijom mogu kombinovano regulisati. Mnoga istraživanja su pokazala da unos pića koja sadrže $4-8 \%$ ugljenih hidrata pruža efikasnu rehidrataciju tokom vežbanja i obezbeđuju koristan izvor energije za mišiće i centralni nervni sistem. Poslednja uputstva za rehidrataciju tokom vežbanja podržavaju korišćenje gotovih sportskih napitaka (4-8\%

Tabela 5. Preporučeni dnevni unos minerala

\begin{tabular}{lll}
\hline Minerali & DRI - odrasli muškarci & DRI- odrasli žene (koje nisu trudne) \\
\hline Kalcijum & $1000 \mathrm{mg}$ & $1000 \mu \mathrm{g}$ \\
Fosfor & $700 \mathrm{mg}$ & $700 \mu \mathrm{g}$ \\
Magnezijum & $400 \mathrm{mg}$ (od 19 do 30 godina) & $310 \mathrm{mg}$ (od 19 do 30 godina) \\
& $420 \mathrm{mg}$ (od 31 do 50 godina) & $320 \mathrm{mg}$ (od 31 do 50 godina) \\
Cink & $11 \mathrm{mg}$ & $8 \mathrm{mg}$ \\
Gvožđe & $8 \mathrm{mg}$ nepušači & $18 \mathrm{mg}$ \\
Fluoridi & $4 \mathrm{mg}$ & $3 \mathrm{mg}$ \\
Mangan & $2,3 \mathrm{mg}$ & $1,8 \mathrm{mg}$ \\
Bakar & $900 \mathrm{mg}$ & $900 \mathrm{mg}$ \\
Jod & $150 \mu \mathrm{g}$ & $150 \mathrm{mg}$ \\
Selen & $55 \mu \mathrm{g}$ & $55 \mu \mathrm{g}$ \\
Molibden & $45 \mu \mathrm{g}$ & $45 \mu \mathrm{g}$ \\
Hrom & $35 \mathrm{mg}$ & $25 \mathrm{mg}$ \\
\hline
\end{tabular}

* starosna dob od 19 do 50 godina

$\mathrm{DRI}=$ Dietary Reference Intake; $\mu \mathrm{g}=$ mikrogram; $\mathrm{mg}=$ miligram

Podaci preuzeti sa: Instituta za Medicinu, SAD, 2000. 
ugljenih hidrata, $10-25 \mathrm{mmol} / \mathrm{L}$ natrijuma) tokom raznih produženih takmičenja i treninga, iako se voda i dalje smatra najprikladnijim pićem za aktivnosti koje traju kraće od 60 minuta (7).

\section{Zaključak}

Osobe koje se bave sportom uvek nastoje da pronađu novi način da unaprede svoje rezultate, a dobra nutritivna strategija je put koji im otvara velike mogućnosti za to. Suptilna korekcija ishrane veoma često može da unapre-

\section{Literatura}

1. http://www.measuresport.eu/news/item/1000000344/sports_clubs_ form_the_heart_of_the_european_sports_sector

2. Reiner M, Niermann C, Jekauc D, Woll A. Long-term health benefits of physical activity - A systematic review of longitudinal studies. BMC Public Health 2013;13:813.

3. Cockburn C, and Clarke G. Everybody's Looking at You! Girls negotiating the 'femininity deficit' they incur in physical education. Women Studies International Forum 2002.25;6:651-665.

4. Mahan LK and Stump SE. „Nutrition for exercise and sports performance", Food Nutrition and Diet therapy. $10^{\text {th }}$ edition, WB Saunders Company; 2000. p. 545.

5. Hottenrott K, Hass E, Kraus M, Neumann G, Steiner M, Knechtle B. A scientific nutrition strategy improves time trial performance by $\approx 6 \%$ when compared with a self-chosen nutrition strategy in trained cyclists: a randomized cross-over study. Appl Physiol Nutr Metab. 2012; 37:637-45

6. Hansen EA, Emanuelsen A, Gertsen RM, Sørensen SImproved marathon performance by in-race nutritional strategy intervention. Int J Sport Nutr Exerc Metab. 2014; 24:645-55.

7. Burke L. Editor. Practical sports nutrition.Champaign, IL: Human Kinetics, 2007.

8. Jeukendrup AA. Step towards personalized sports nutrition: carbohydrate intake during exercise.Sports Med. 2014; 44:25-33.

9. Mudambi SR, Rajagopal MV. Fundamentals of Foods and Nutrition. (4th ed): New Delhi: Wiley Eastern Limited, 1989.

10. Okely AD, Booth ML et Chey T. Relationships between body composition and fundamental movements skills among children and adolescents. Research Quarterly for Exercise and Sport 2004; 75:238-247.

11. Benardot D. Napredna sportska ishrana, Beograd: Data Status, 2010.

12. Hinton PS, Stanfor TC, Davidson MM, Yakushko OF. et Beck NC. Nutrient intake and dietary behaviors of male and female collegiate athletes. International Journal of Sport Nutrition and Exercise Metabolism 2004;14:389-405.

13. Sundgot-Borgen J. et Torstveit M.K. Prevalence of eating disorders in elite athletes is higher than in the general population. Clinical Journal of Sport Medicine 2004; 14:25-32.

14. Dosil J, González-Oya J. Eating disorders in athletes. Chichester, West Sussex, England: John Wiley \& Sons, Ltd; 2008. Eating disorders and the Athlete's environment; pp. 41-63.

15. Werner A, Thiel A, Schneider S, Mayer J, Giel KE, Zipfel A. Weight-control behaviour and weight-concerns in young elite athletes - a systematic review.J Eat Disord. 2013; 1:18.

16. Klissouras V. Osnovi sportske fiziologije; [translated by Andjelkovic M. et al.]; Dikić N. Beograd: Institut za sport, 2013.

17. Wagenmakers AJ, Beckers EJ, Brouns F, Kuipers $H$, Soeters PB, van der Vusse GJ, et al. Carbohydrate supplementation, glycogen depletion, and amino acid metabolism during exercise. Am J Physiol 1991; 260:883-890.

18. Bosch AN, Dennis SC, Noakes TD. Influence of carbohydrate loading on fuel substrate turnover and oxidation during prolonged exercise. J Appl Physiol 1993; 74:1921-1927. di takmičarski rezultat za mali deo sekunde ili nekoliko milimetara koliko je često dovoljno za pobedu. Od suštinskog značaja je da sportisti i treneri nauče da procene koji je unos energetskih materija potreban i kakav treba da bude odnos ugljenih hidrata, masti i proteina u svakom obroku, sa ciljem da se obezbede optimalne mentalne i mišićne funkcije neophodne za sport kojim se bave. Dobar program ishrane, osmišljen na vreme, optimalno dizajniran i sa realnim ciljevima treba da bude osnov koji bi svakom ozbiljnom sportisti bio na raspolaganju. Samo ispunjeni nutritivni zahtevi mogu da preveniraju deficite i unaprede sportske performanse do krajnjih granica.

19. Coggan AR, Coyle EF. Reversal of fatigue during prolonged exercise by carbohydrate infusion or ingestion. J Appl Physiol 1987; 63:2388-2395.

20. USDA/HHS. Nutrition and your health: Dietary guidelines for Americans. Home and Garden bulletin br. 232. Washington DC: Goverment Priniting Office. 2000.

21. Noakes T, Volek JS, Phinney SD. Low-carbohydrate diets for athletes: what evidence? Br J Sports Med. 2014; 48:1077-8.

22. Kiens B. i Helge J.W. Adaptations to a high fat diet.In:Nutrition in sport (Ed.Maughan R.J.).London:Blackwell Science. 2000; 192-202.

23. Jukendrup AE, Saris WHM, Schrauwen P, Brouns F et Wagermakers AJM. Metabolic availability of mediumchain triglycerides increase energy expenditure and decrease adiposity in overweight men. Obesity Research 2003; 11:395-402.

24. Brilla LF et Lanerholm TE. Effect of fish oil supplementation and exercise on serum lipids and aerobic fitness. Jurnal of Sports Medicine 1990; 30:173.

25. Huffman DM, Altena TS, Mawhinney TP et Thomas TR. Effect on n-3 fatty acids on free tryptophanand exercise fatigue. European Journal of Applied Physiology 2004; 92:584-91.

26. Lenn J, Uhl T, Mattacola C, Boissonneault G, Yates J, Ibrahim W. et Bruckner $\mathrm{G}$. The effects of fish oil and isoflavones delayed onset muscle soreness. Medicine \& Science in Sports and Exercise 2002; 34:1605-13.

27. Meredith CN, Zackin MJ, Frontera WR et Evans WJ. Dietary Protein requirements and body protein metabolism in endurance-trained men. Journal of Applied Physiology 1989; 66:2850-2856.

28. Butterfield GE et Calloway DH. Physical activity improves protein utilization in young men. British Journal of Nutrition,1984; 51:171-184.

29. Meredith CN, Zackin MJ, Frontera WR et Evans WJ. Dietary Protein requirements and body protein metabolism in endurance-trained men. Journal of Applied Physiology,1989; 66:2850-2856.

30. Butterfield G, Cady C et Moynihan S. Effect of increasing protein intake on nitrogen balance in recreational weight lifters. Medicine \&Science in Sports\&Exercise, 1992; 24:71.

31. Tarnopolsky MA, MacDougall JD. et Atkinson SA Influence of protein intake and traning status on nitrogen balance and lean body mass. Journal of Applied Physiology, 1988;64(1):187-193.

32. Pingitore, Alessandro et al. Exercise and oxidative stress: Potential effects of antioxidant dietary strategies in sports Nutrition , 2015; 31:916 $-922$.

33. Driskell J. Summary: Vitamins and trace elements in sports nutrition. In: Driskell J, Wolinsky I, editors. Sports Nutrition. Vitamins and Trace Elements. New York (NY): CRC/Taylor \& Francis; 2006. p. 323-31.

34. Lukaski HC. Vitamin and mineral status: effects on physical performance. Nutrition. 2004; 20:632-44.

35. Hargreaves M. Physiological benefits of fluid and energy replacement during exercise. Australian Journal of Nutrition and Dietetics 1996; 53:3-7. 